\title{
Teknolojik Yeniliklerin Bankacılık Hizmetlerine Etkisi: Türk Bankaları Üzerinde Bir Değerlendirme (Araştırma Makalesi)
}

\author{
The Impact of Technological Innovations on Banking Services: An Evaluation \\ on Turkish Banks
}

Doi: 10.29023/alanyaakademik.659189

Mübeyyen TEPE KÜÇÜKOĞLU

Dr. Ö $\breve{g} . \ddot{U y e s i}$, Trakya Üniversitesi, Keşan Yusuf Çapraz Uygulamalı Bilimler Yüksekokulu mtepekucukoglu@trakya.edu.tr

Orcid No: 0000-0002-3717-4165

\section{Meltem AKCA}

Dr. Öğ. Üyesi, Alanya Alaaddin Keykubat Üniversitesi, Gazipaşa Havacılık ve Uzay Bilimleri Fakültesi, Havacılık Yönetimi Bölümü

meltem.akca@alanya.edu.tr

Orcid No: 0000-0001-5544-5929

Bu makaleye atıfta bulunmak için: Tepe Küçükoğlu M. \& Akça, M. (2020). Teknolojik Yeniliklerin Bankacılık Hizmetlerine Etkisi: Türk Bankaları Üzerinde Bir Değerlendirme. Alanya Akademik Bakış, 4(2), Sayfa No.223-244.

\begin{tabular}{|c|c|}
\hline & \\
\hline & \multirow{6}{*}{$\begin{array}{l}\text { Teknolojinin getirdiği yenilikler çeşitli sektörlerle birlikte bankacılık } \\
\text { sektörünü de etkilemiştir. Sektörde rekabetin artmasıyla birlikte teknolojik } \\
\text { yenilikler bankaların stratejilerinin önemli bir parçası olmuştur. Mevcut } \\
\text { bankacılık işlemlerinin kolaylaşmasını sağlayan çeşitli uygulamalar müşteri } \\
\text { açısından işlem kolaylığı ve zaman tasarrufunun yanı sıra, bankalar } \\
\text { açısından mevcut şube ve personele olan ihtiyacın azalması gibi birtakım } \\
\text { avantajları da beraberinde getirmektedir. Bu noktadan hareketle, teknolojik } \\
\text { yeniliklerin ve bu yenilikler sonucu ortaya çılkan elektronik dağıtım } \\
\text { kanallarının bankacılık hizmetlerine olan etkilerini incelemeyi amaçlayan bu } \\
\text { çalışma ortaya çımıştır. Bankacılık sektöründe çalışan } 246 \text { personelin } \\
\text { katılımıyla gerçekleştirilen anketçalışmasının bulgular değerlendirilmiştir. }\end{array}$} \\
\hline \multirow{2}{*}{$\begin{array}{l}\text { Anahtar kelimeler: } \\
\text { Teknoloji Kullanımı, } \\
\text { Bankacılı Sektörü, } \\
\text { Bilgi Teknolojileri }\end{array}$} & \\
\hline & \\
\hline & \\
\hline & \\
\hline & \\
\hline
\end{tabular}

Keywords:

\section{ABSTRACT}

The innovations brought by technology have affected the banking sector Technology Usage, Banking Services, Information Technologies along with various sectors. With the increasing competition in the sector, technological innovations have become an important part of the strategies of banks. Various applications that facilitate the existing banking transactions bring some advantages such as the ease of transactions and time savings for the customer, as well as the decrease in the need for existing branches and personnel for banks. From this point of view, this study aimed to examine the effects of technological innovations and the electronic distribution channels that arise as a result of these innovations on banking services. The findings of the survey conducted with the participation of 246 employees working in banks. 


\section{GİRIŞ}

Uluslararası ekonominin genişlemesi, küreselleşme etkisiyle kurumsal yapı ve piyasaların bir bütünlüğe doğru dönüşümü bankacılık sektörünün hızlı bir değişim döngüsü içerisinde olmasına zemin hazırlamıştır. Bu değişim sürecinde yaşanan gelişmeleri tetikleyen en önemli unsurun coğrafya, endüstri ve sistemlerin getirdiği engelleri aşan, yeni ürünler, hizmetler ve pazar firsatları yaratan ve daha fazla bilgi ve sistem odaklı iş ve yönetim süreçleri geliştiren teknolojilerin olduğunu söylemek mümkündür (Liao ve Cheung, 2002: 283).

1980'den itibaren finans sektörü ve bankacılık hizmetleri açısından teknolojik gelişmelerin etkisiyle yeni bir süreç baş göstermiştir. $\mathrm{Bu}$ süreç bankacılık sektörü açısından yeniden yapılanma ve modernizasyon süreci olarak adlandırılmaktadır (Yetiz ve Ergin Ünal, 2018:117). Mevcut bankacılık süreçleri değişerek teknolojik gelişmeler paralelinde güncel hizmetlerle ve araçlarla yeniden şekillenmiştir. Otomatik para çekme makinaları (ATM), bankamatik ve kredi kartları, internet bankacılığı, elektronik fon transferi (EFT) gibi unsurlar bu hizmet ve araçlara örnek teşkil etmektedir. Bankacılık sektöründeki teknolojik modernizasyon ile mevcut süreçlerin daha etkin ve verimli bir şekilde gerçekleştirilmesi hedeflenmektedir (Giatsidis vd., 2019).

Bankacılık sektörü her zaman bilgi yoğunluğu yüksek faaliyetler içeren ve bilgiyi elde etme, işleme ve ilgili kullanıcılara sunmada teknoloji kullanımına bağımlı bir sektör olmuştur (Tan ve Teo, 2000:2). Bilgisayar teknolojisindeki gelişmeler, artan rekabet, maliyet unsuru, bilgi toplumunun talepleri, yeni hizmet ve ürün anlayışı ile yeni sistemin sağladığı verimlilik bankacılık sektörünü teknolojik araçları kullanmaya yönelten faktörler olarak dikkat çekmektedir (Güvenç ve Yücebalkan, 2017:41; Abbas vd., 2014:272). Sektördeki teknik değişiklikler devrim niteliğinde bir karakter sergilemektedir (Buzzacchi vd., 1995:151). Bankacılık hizmetlerinde gözlenen yeniliklerin çoğu diş kaynaklardaki fikirleri temel almakla birlikte, söz konusu yenilikler rakip bankalar arasında da hızla yayılmaktadır (Roberts ve Amit, 2003:107). Bankacılık sektöründeki finansal yenilikler sayesinde işlem maliyeti ve riski azalarak, rekabet canlı tutulmakta, kıt kaynakların daha etkin kullanılması sağlanmaktadır. Sektörde rekabetin artması müşterilere olan bakış açısını değiştirerek ve iş stratejilerinin yeniden tanımlanmasında etkili olmaktadır (Aliyu ve Tasmin, 2012; Flavin vd., 2006). Ayrıca, bankalar müşterilerine daha iyi hizmet verebilmek amaciyla finansal yeniliklerden faydalanarak yeni finansal araçlar geliştirmektedirler (Reis vd., 2013:34; Yetiz ve Ergin Ünal, 2018:119). Bu kapsamda, finansal yenilik kavramı mevcut finansal araçların yeterli olmaması nedeniyle, finansal hizmetlerin yeni ürün ve hizmetlerle daha etkili bir biçimde gerçekleştirilmesi amacıyla ortaya çıkan değişimler olarak tanımlanmaktadır. Kişisel bilgisayarlarla finansal işlemler, repo, swap, futures, opsiyon işlemleri gibi işlemler finansal yenilik örnekleridir (Van Horne, 1985; Türkiye Cumhuriyeti Merkez Bankası, 2015). Finansal yenilikler, mevcut araçların modifikasyonu ve yeni kullanım alanları geliştirilmesiyle oluşan ya da finansal piyasalar, kurumlar, araçlar ve düzenlemelerde ortaya çıkan yeni gelişmeler şeklinde ele alınmaktadır (Balaylar ve Duygulu, 2016:383; Blach, 2011:19). Teknolojik araçların finansal yeniliklerin kullanım alanını genişletmesi ile birlikte bankaların geleneksel yapısı değişerek bilgiye ulaşım maliyetleri azalmakta ve sunulan hizmetler bilgisayar kullanımıyla her geçen gün daha da kolaylaşmaktadır (Yetiz ve Ergin Ünal, 2018:119; Ugwu vd., 2000; Abbas vd., 2014). 
Bu çalışmada, bankacılık sektöründeki teknolojik gelişmeler kavramsal çerçevede ele alınmış ve araştırma kısmında Türkiye'de faaliyet gösteren banka şubelerinde çalışan personelin katılımıyla teknolojik yeniliklerin finansal faaliyetlerdeki etkisi analiz edilmiştir.

\section{BANKACILIK SEKTÖRÜ VE TEKNOLOJI}

Günümüz iş hayatında, küreselleşme ve teknolojik değişim işletmeler arasındaki rekabeti arttırmıştır (Kumar, 2019). Dünya genelinde artan finansal rekabet, tüketici ihtiyaçlarındaki hızlı değişim bankaları finansal yenilikleri izleme, yenilikleri oluşturma ve yenilikleri ilk piyasaya süren kurumlar olmaya zorlamaktadır. Bu nedenle değişen ekonomik koşullara uymak için bankalar sundukları hizmetlerde yenilik ve çeşitliliğe gitmektedirler (Reis vd., 2013:43; Yetiz ve Ergin Ünal, 2018:123). Bilgi teknolojilerinin bilginin işlenmesinin yanı sıra bankaların ürün ve hizmetlerinde farklılaşabilmelerine imkân sağlayan kritik bir unsur olması, sektördeki yeniliklerin oluşumunu tetiklemektedir (Tan ve Teo 2000:2). Günümüzde, bankacılık sektörünün teknoloji olmadan hayatta kalamayacağı bir gerçektir. Aksi halde, hizmetler yavaşlar ve mevcut hizmetlerin ve müşteri deneyiminin dışında bir durum oluşur. $\mathrm{Bu}$ nedenle, mevcut bankacılık işlemlerinde teknolojik yenilikler sayesinde müşterilerin günlük hayatlarının hizmetlerin otomasyonuyla ciddi düzeyde kolaylaştığı, tüm operasyonların müşterilerce gerçekleştirilebildiği ve zaman tasarrufu sağlandığ1 görülmektedir (Abbas vd., 2014; Reis vd., 2013:37; Ugwu vd., 2000). Diğer taraftan müşteri beklentilerinin belirlenerek bu beklentileri doğru bir şekilde karşılayacak stratejiler tanımlanırken bu stratejilere uygun teknolojilerin de içselleştirilmesi bankacılık hizmetlerinin modernizasyonu ve kullanımında etkili olan bir faktör olarak değerlendirilmektedir (Işın, 2006:108). İlerleyen teknolojiler sayesinde artık banka şubelerine gitmeden birçok bankacılık işlemi kolaylıkla gerçekleştirilebilmektedir. Banka şubelerine gidilmeden gerçekleştirilecek işlemleri aşağıdaki örneklerle ele almak mümkündür (Rose, 2020; Gupta vd., 2020; Koçak ve Özbek, 2019:88-89; Yurttadur ve Süzen, 2016:94-95; Ar1kan 2015:40; Erol vd, 2015:1).

- İnternet Bankacılığı,

- Telefon Bankacilı̆̆1,

- Mail-Order Sistemi,

- Otomatik Ödeme Makinaları (ATM) Bankacılığı,

- Görüntülü Ödeme Makinaları (VTM) Bankacılığı,

- Satış ve Hizmet Noktası (POS) Bankacılığı

- Mobil (Cep telefonuyla internet bağlantılı) Bankacılık,

- Televizyon Bankacilı̆̆1,

Günümüzde başarılı bankaların özellikleri arasında teknolojiyi yaygın olarak kullanmak, katma değeri yüksek yenilikçi ürünler sunmak gibi unsurlar öne çıkmaktadır (Işın 2006:118) Daha çok yenilikçi faaliyetlerde bulunan, bu faaliyetlerinde daha tutarlı olan ve söz konusu yenilikçi faaliyetin sektör için farklılık sunduğu durumlarda bankanın finansal performansının yükseldiği belirtilmektedir (Roberts ve Amit 2003:107).

Bankacılık sektöründe bilgi ve iletişim teknolojilerinin kullanımı ile örgütsel ve süreçsel yapılarda da değişiklikler yaşanmaya başlamıştır. Banka şubelerindeki çalışan sayısı azalmış ancak buna karşılık mevcut personelin bilgi, nitelik ve yetkinliklerinin genişlemesi ihtiyacı doğmuştur (Pinto ve Ferreira 2010:56). İnsan kaynakları açısından bakılacak olursa, bankacılık sektöründe sürdürülebilir bir dönüşümün ancak çalışan odaklı bir yaklaşım ile gerçekleşeceği vurgulanmaktadır. Bu doğrultuda geleneksel rollere sahip bankacıların yerine 
yeni roller ile birlikte görev tanımlarının temelden değişim göstereceği bir organizasyon yapısının oluşacağı belirtilmektedir (EY Türkiye, 2015).

Bilgi ve iletişim teknolojilerinin yoğun olarak kullanılması ile birlikte bankacılık sektöründe değişen dinamikleri Güvenç ve Yücebalkan (2017) şu şekilde özetlemektedir:

- Hizmet hattında şubelerden teknolojik birimlere dönüşümle birlikte işlerin yapılış süresi azalırken iş çeşidi ve sayısı artmıştır.

- Şubeler küçülüp şube sayısı artarken, şube başına çalışan sayısı azalmış ve operasyon merkezleri büyümüştür.

- İşgücü açısından yaş ortalamasının düştüğü ve kadın istihdamının arttığı, kapsamlı ve karmaşık teknolojiyi kullanabilecek işgücüne talebin genişlediği görülmüştür.

- İş modelleri ve iş yapış şekillerinin değişimimle birlikte otokontrol, rotasyon, iş genişlemesi, katılımcı yönetim, kurum içi eğitimler yaygınlaşmıştır.

Özetlemek gerekirse; teknolojik yeniliklerle birlikte mevcut yapıya yeni bölümler eklenerek müşterilere alternatif araçlar ve ürünler sunulması mümkün olmuş, daha geniş ve yeni müşteri kitlesine ulaşılmasına zemin hazırlanmıştır. Bankacılıkta sunulan hizmetlerin hızlanması, işlem maliyetlerin azalması ve hatta çoğu hizmetlerin bankalara gitmeye gerek kalmadan internet ve mobil bankacılık aracılığı ile gerçekleştirilmesi sağlanmıştır. Böylece müşteri memnuniyeti ve devamında da müşteri sadakatinin artması hedeflenmiştir. Finansal ve teknik yenilikler, bankalardaki bilgi akış sisteminin standartlaşmasına, etkinliğin sağlanmasına, aynı işlemlerin tekrarının engellenmesine ve daha kısa zamanda daha fazla işlem yapılabilmesine olanak sağlamış, bankacılık işlemleri kolaylaşmıştır. Türk bankacılık sektörü böylece hem ulusal hem de uluslararası alanda daha rekabetçi ve güçlü bir yapıya kavuşmuştur (Işın 2006:108; Yetiz ve Ergin Ünal 2018:133; Ghasemi vd., 2011).

Diğer taraftan, sunulan yeni finansal ürün ve hizmetler risk, belirsizlik ve karmaşıklık derecelerinin artırmasına neden olmaktadır. Bununla birlikte, yeni finansal araçlar ve ürünler oluşturmak için daha fazla finansman olanaklarına ve Ar-Ge çalışmalarına ihtiyaç duyulmaktadır. Ayrıca, çalışanların yenilikleri tanımaları, benimsemeleri ve kullanılan teknolojilere hâkim olmaları için eğitim maliyetleri ortaya çıkmaktadır (Abbas vd., 2014). Teknolojik yeniliklerin getirdiği yeni araçlarla birlikte banka şubesi ve şube elemanlarına olan talebin azalacağı ya da daha fazla uzmanlaşmış kalifiye işgücü istihdamına yönelik ihtiyacın artacağı beklenmektedir (Yetiz ve Ergin Ünal 2018:133).

\subsection{Teknoloji Kullanımına İlişkin Literatür Taraması}

Bilgisayar sistemlerinin gelişmesi, internet kullanımının yaygınlaşması insan yaşamında teknoloji kullanımı üzerinde belirleyici olmaktadır. Bireysel açıdan teknoloji kullanımının insan yaşamını kolaylaştırma özelliği ön plana çıkarken, örgütsel yaklaşımlara göre teknoloji kullanımının daha iyi iş çıktıları oluşturarak performans ve karlılık üzerinde etkili olması hedeflenmektedir. Bu kapsamda, ilgili literatürde teknoloji kullanımına yönelik oluşturulan kuramlarda kullanıma yönelik davranışlar ile ilişkili faktörler irdelenmiştir.

Fishbein ve Ajzen (1975) tarafından sosyal psikolojide insan davranışını açıklamak için oluşturulmuş Sebeplendirilmiş Davranış Teorisine göre, kişinin belirli bir davranışa yönelik performansı (teknoloji kullanımı) kişinin o davranışı gerçekleştirmeye yönelik niyeti ile açıklanabilmektedir ve davranışsal niyet bireyin tutumu ve normları ile ilişkilidir (Suryaningrum, 2012:113). Bu modele göre bir eyleme yönelik davranış, kişinin daha önceki 
düşüncesi, inancı ve deneyiminden etkilenmektedir. Planlanmış Davranış Teorisi ise (Ajzen, 1991) Sebeplendirilmiş Davranış Teorisine algılanan davranışsal kontrol değişkeninin eklenmesiyle oluşmuştur. Bireyin belirli bir davranışa yönelik performansı, bireyin o davranışı gerçekleştirmesine ilişkin niyetini şekillendirmektedir. Davranışın arkasındaki tutum ise bireysel davranışının gerçekleşmesinde olumlu ya da olumsuz yönde etkilidir. $\mathrm{Bu}$ bağlamda, bireyin davranışı üzerinde etkisi olan ve motivasyonel unsurlar ile davranışın istenilen şekilde gerçekleştirilmesine odaklanılması Planlanmış Davranış Teorisi çerçevesinde ele alınmaktadır. Doll ve Torkzadeh (1988) de bilgi teknolojilerine yönelik oluşturdukları Son Kullanıcı Tatmin Modelinde, bilgi teknolojilerinin biçimi, kapsamı, kesinliği, kullanım kolaylığı ve güncelliğinin kullanım tatmini sağlayacağını ifade etmişlerdir. Yazarlar, bilgi teknolojileri kullanımının, ele alınana boyutlara ilişkin kullanım tatmini ile gerçekleştiği vurgulanmaktadir.

Delone ve McLean'in (1992) Enformasyon Sistemleri Başarı Modelinde bilgi sistemleri kullanıcıları ve sistem arasındaki etkileşimin çıkardığg sonuçlar incelenmiştir. Teknoloji kullanıcılarının memnuniyet düzeyi, sistemin özellikleri ve sistemin ürettiği bilginin kalitesinden etkilenmektedir. Delone ve Mclean (1992) bu modelde organizasyonel sonuçların oluşumunda etki edebilecek tek faktörün sistem özellikleri olduğunu ele aldıkları için sonraki yıllarda çeşitli araştırmacılar tarafından eleştirilmişlerdir. Davis (1989) ise, Teknoloji Kabul Teorisinde, bilgi teknolojilerine yönelik algılanan kullanışlılık ve algılanan kullanım kolaylığının sistemlerin kullanımını etkilediğini ortaya çıkarmıştır. Davis (1993), algılanan kullanım kolaylığının algılanan kullanışlılık üzerine etkili olabileceğini belirtmektedir. Algılanan kullanışlılık; bireyin bir sistemi ya da teknolojiyi kullanmasının kişisel performansını arttıracağına yönelik inanç düzeyi olarak tanımlamaktadır. Algılanan kullanım kolaylığı ise bireyin bu teknolojiyi fiziksel ve mental olarak çaba sarf etmeden gerçekleştirebileceğine yönelik inanç düzeyi olarak ele alınmaktadır (Davis, 1993). Bireyin teknolojiye yönelik kullanım kolaylığı ve kullanışlılık algısı yüksek ise kullanım performansı da artış göstermektedir (Richad vd., 2019). Suping ve Yizheng (2010) bankacılık sektöründe bilgi teknolojilerinin kullanım kolaylığının ve kullanışlılığının internet bankacılığ işlemlerine etkisinin yanı sıra çalışanlar üzerinde de olumlu etkilerinin olduğunu vurgulayarak ve iş çıktılarının kalitesinin yükseldiğini belirtmişlerdir.

Bir başka yaklaşıma göre, Görev-Teknoloji Uygunluğu Kuramı (Goodhue-Thompson,1995) da bilgi teknolojileri kullanılarak çalışan performansını arttırmanın yeterli olmadığı, kullanılan bilgi teknolojileri ile görev özelliklerinin de uyumlu olması gerektiğini savunmaktadır (Bozaykut vd., 2016). Görev ve teknoloji özelliklerinin ahenkli olması, amaçlara erişimin sağlanmasına ve teknolojik yatırımlardan beklenen çıktıların oluşumuna katkı sağlamaktadır. Son olarak, Teknoloji Kabul ve Kullanımı Birleştirilmiş Modeli ise teknoloji kullanım niyeti ve davranışının altında yatan etkileri de ele almaktadır. Bu modelde, performans beklentisi, çaba beklentisi, sosyal etki gibi unsurların davranış niyeti üzerinde etki ederek bilgi teknolojilerine yönelik kullanım davranışının belirleyicisi olabildikleri vurgulanmaktadır (Venkatesh vd., 2012).

Günümüz bankacılık sektöründe internet bankacılığı önemli bir dağıtım kanalı olarak ele alınmaktadır. Teknoloji ile donatılmış hizmetlere yönelik yatırımların amacı hem yeni müşterileri bankaya çekmek, hem de mevcut müşterileri elde tutmaktır (Kaya ve Arslan, 2016:446). Pinto ve Ferreira (2010), yeni teknolojilerin bankacilık hizmetlerine etkilerini ve yayılımını Portekiz'in belli bir bölgesini ele alarak incelerken; ülke geneli ile de bir 
karşılaştırma yapmışlardır. Benzer bir çalışmada, Reis, Ferreira ve Barata (2013), teknolojik yeniliklerin finansal hizmetlere olan temel etkilerini Portekiz'deki banka şubeleri düzeyinde inceleyerek çıkarımlarda bulunmuşlardır. Buzzacchi ve arkadaşları (1995) bankacılık sektöründe bilgi teknolojilerinin yayılmasından kaynaklanan yenilikleri İtalya bankacılık sektörünü inceleyerek analiz etmişlerdir. Roberts ve Amit (2003)1981-1995 yılları arasında yeni ürün ve süreçlerin Avusturalya'daki perakende bankacılık sektöründeki adaptasyon sürecini inceleyerek inovasyon ile finansal performans arasındaki ilişkiyi çeşitli senaryolar içeren hipotezlerle test etmişlerdir.

Damanpour ve Gopalakrishnan (2001), Amerika'da yer alan 101 ticari bankanın 1982-1993 yılları arasında gerçekleşen yeniliklere ait verilerini kullanarak bir çalışma yürütmüşlerdir. Ürün yeniliklerinin süreç yeniliklerine oranla daha yüksek oranda ve hızda gerçekleştiği, yüksek performansa sahip bankaların ürün ve süreç yeniliklerini düşük performansa sahip bankalara göre daha eşit bir şekilde gerçekleştirdiği şeklinde bulgulara ulaşmışlardır.

Liao ve Cheung (2002), finansal bir yenilik olan internet tabanlı bankacılığa yönelik tüketici tutumlarını ölçmek ve talep tarafındaki uygulanabilirliği ve beklentileri keşfetmek için bir analiz yapmışlardır. Analiz sonucunda; doğruluk, güvenlik, işlem hızı, kullanıcı dostu olma, kullanıcı katılımı ve rahatlığa ilişkin bireysel beklentilerin en önemli kalite nitelikleri olduğu ortaya çıkmıştır.

Yetiz ve Ergin Ünal (2018) Türkiye'deki bankacılık sistemindeki finansal yeniliklere bağlı olarak geliştirilen ürün ve süreç yeniliklerini bütünsel bir bakış açısıyla değerlendirerek, olumlu ve olumsuz taraflarını irdelemiş ve önerilerde bulunmuştur. Benzer bir çalışma da Işın (2006) tarafından gerçekleştirilmiştir. Söz konusu çalışmada, teknoloji araçlarının bankacılık sektöründe uygulanabilirliği (kredi kartları, ATM, internet bankacılığı, EFT, SWIFT vb) 22 banka üzerinden değerlendirilmiştir. Bankacılık sektöründe teknoloji ile işgücü arasındaki ilişkiye değinen Güvenç ve Yücebalkan (2017), bir bankanın çalışanları ile mülakatlar yapmışlar, ardından da elde edilen veriler doğrultusunda çeşitli uzmanlarla görüşmeler gerçekleştirerek teknolojik dönüşümün işgücüne yansımalarını analiz etmişlerdir. Uzun ve Berberoğlu (2018) da internet bankacılığının, bankaların finansal performansına olumlu katkısının olduğunu saptamışlardır. Erol ve arkadaşları (2015) bankalarda bilgi teknolojileri kullanımının işlemlere yönelik hızlılığ 1 arttırmakla birlikte maliyet minimizasyonu sağlayarak kontrol mekanizmasını güçlendirdiğini belirtmektedir. Ayrıca, bilgi teknolojileri kullanımı, personel, kırtasiye, kira ve reklam gibi çeşitli giderlerin azalmasında da etkili olmaktadır (Aytar vd., 2012:4). Bununla birlikte bilgi teknolojileri kullanılarak yapılan bankacılık işlemlerine yönelik ücretlerden edilen çeşitli gelirler de bankaların finansal performansına katk1 sunmaktadır (Erol vd.,2015:19).

Mocetti ve arkadaşları (2017) İtalya'da yürüttükleri araştırmalarında bilgi ve iletişim teknolojileri kullanımı ile yetki devri gücü arasında pozitif bir ilişkinin olduğunu saptamışlardır. 142 banka çalışanı üzerinde yürütülen başka bir araştırmada bilgi ve iletişim teknolojileri kullanımın çalışanların performansı, iş tatmini, üretkenlikleri üzerinde pozitif etkiye sahip oldukları ortaya çıkarılmıştır(Oo,2018). Nath ve arkadaşları (2013) özel ve kamu bankalarında çalışan 238 çalışan üzerinde yürüttükleri araştırmalarında, bilgi ve iletişim teknolojilerine ilişkin kullanım kolaylığının kullanım tutumu üzerinde pozitif etkisi olduğunu saptamışlardır. Malik ve Sattar (2017) ise kamu ve özel bankalarda çalışan 252 çalışanın katılımıyla gerçekleştirdikleri araştırmalarında çalışanların teknolojiye yönelik algıları ile örgütsel performans arasında ilişki olduğu sonucuna ulaşmışlardır. Ku ve Ye'de (2010) 228 
benzer katılımcı grubunda yaptığı araştırmalarında performans ve teknoloji kullanımına yönelik algı arasında ilişki olduğunu ortaya çıkarmıştır.

Başka bir çalışmada, Abbas ve arkadaşları (2014) 32 banka çalışanı ile mülakat gerçekleştirmiş ve elde edilen bilgileri analiz etmişlerdir. Çalışma sonucunda, bilgi teknoloji kullanımının bazı işleri otomatikleştirerek kolaylık sağladığ 1 saptanmıştır. Çalışanların günlük işlere yönelik işlem sürelerinin azaldığı vurgulanmıştır. Çalışan performansının arttığ1 belirtilmiştir. Kullanıcı dostu teknoloji kullanımının işleri kolaylaştırarak faaliyetlere ilişskin kontrol sayısını azalttığı ifade edilmiştir. Çalışmada, yeni teknolojilere yönelik eğitim ihtiyacının iyi yönetilmesi gerekliliğinin de altı çizilmiştir. Mülakata katılan çalışanların büyük kısmı bankacılık işlemlerinde kullanılan teknolojilere yönelik verilen eğitimlerden tatmin olmadıklarını ve kullanım esnasında zorluklar yaşadıklarını dile getirmişlerdir. Richad ve meslektaşları (2019) ise Endonezya'da yürüttükleri çalışmalarında bankacılık sektöründe kullanılan bilgi teknolojilerinin yenilikçi, kullanışlı ve kullanım kolaylığına sahip olmasının teknolojik ürünlerin kullanım niyetini etkilediğini saptamışlardır.

\section{METODOLOJI}

Bankalar ekonomide finansal aracılık fonksiyonu kanalıyla fon fazlasını fon açığı olan verimli alanlara yönlendirerek kaynakların etkin bir şekilde kullanımı sağlayan kurumlardır. Türkiye'de bankacılık sektörü finansal piyasalar içinde fon akışını gerçekleştiren rekabetçi sektörlerin başında gelmektedir (Yetiz ve Ergin Ünal 2018:123). Ayrıca, diğer ülkeler gibi Türkiye'de de sanayi işletmelerinin kurulması ve gelişiminde, ticari hayatta iş ve işlemlerin bir güven ortamı içerisinde, kolay ve sağlıklı bir şekilde yürütülmesinde, kurumsal ihtiyaçlar dişında bireylerin de ödeme, mevduat, kredi, tasarruf, transfer gibi işlemlerinde banka sisteminin önemli bir rolü bulunmaktadır. Sunulan hizmetler ve bilanço yapısı itibariyle Türk bankaları son derece güçlü ve özerk kurumlardır (Sümer 2016:505). Bununla birlikte, Türkiye'de bankacılık sektörü büyüme aşamasında olup ve bu durumun istikrarlı bir biçimde devam edeceği düşünülmektedir (Yetiz 2016:116). Türkiye'de teknolojik bankacılığın gelişimini henüz tamamlamamış olduğu ve bu durumda teknolojik gelişimin finansal okuryazarlığın düşüklüğü nedeniyle belirli bir kesime ulaştığı söylenmektedir (Güvenç ve Yücebalkan 2017:42). Bu nedenle bu çalışmada bankacılık sektörü ele alınmış ve bilgi teknolojileri kullanımına yönelik etkilerin neler olduğu saptanmaya çalışılmıştır.

Bu çalışmanın ana amacı teknolojik yeniliklerin bankacılık sektöründe finansal hizmetlerdeki esas etkilerini ortaya çıkarmaktır. Bu sebeple, doğru bir analiz yapabilmek maksadıyla literatürden elde edilen soru formu vasıtasıyla veri toplama amaçlanmıştır. Teknolojik yeniliklerin bankacılık sektöründeki etkilerinin gerçekçi bir analizi için çeşitli bankacılık operasyonlarını gerçekleştiren ve müşteri ile direkt temasta olan banka çalışanlarının katılımı hedeflenmiştir. Bankacılık sektöründe Mart 2019 verilerine göre 53 banka faaliyet göstermektedir. Mevduat bankaları sayısı 34, kalkınma ve yatırım bankaları sayısı 13, katılım bankaları sayısı 6'dır. Toplam şube sayısı ise 10.412'dir (Türkiye Bankalar Birliği, 2019). Bu kapsamda, Edirne ilinde faaliyet gösteren mevduat bankalarının çalışanları araştırmanın evrenini oluşturmaktadır. Türkiye Bankalar Birliği 2018 y1lı verilerine göre Edirne'de bankacılık sektöründe çalışan sayısı 769'dur. Yapılan örneklem formulasyonu (Bartlett vd., 2001) sonucunda 13 bankanın farklı şubelerinde faaliyet gösteren çalışanlara 350 adet anket formu kolayda örnekleme yöntemi ile dağıtılmıştır. 10 gün sonunda elde edilen anketler incelenmiş ve 246 anket verisinin uygun olduğuna karar verilmiştir. 
Araştırmada kullanılan soru formu Reis, Ferreira ve Barata'nın (2013) çalışmasından uyarlanmıştır. Söz konusu soru formu dört bölümden oluşmaktadır. İlk bölümde bankacılıkta finansal hizmetlerdeki teknolojik yeniliklerle ilgili mevcut durumun tespit edilmesine yönelik sorular yer almaktadır. İkinci bölümde ise, yeni teknolojilerin kullanımı ve banka çalışanlarına etkisine ilişkin sorular bulunmaktadır. Üçüncü bölüm, bankacılık sektöründe gelişme aşamasındaki yenilikçi eğilimlerle ilgili tahminlere ayrılmıştır. Kullanılan ölçekte yer alan ifadelere katılım düzeyini belirlemek amacıyla Beşli Likert Sisteminden faydalanılmıştır (1-En düşük önem derecesi tanımlarken, 5-en yüksek önem derecesini ifade etmektedir). Son bölümde de, soru formunu yanıtlayan katılımcı bilgilerine yönelik tanımlayıcı sorular mevcuttur. Ayrıca bazı sorularda katılımcılara seçenekler sunulmuştur. Elde edilen veriler düzenlendikten sonra oluşturulan tablolar yardımıyla çalışmanın sonuçları bankacılık sektöründen bir uzman görüşüyle tekrar değerlendirilmiştir.

Demografik verilere ilişkin bilgiler incelendiğinde; katılımcıların yaklaşık yarısı (47\%) 31-40 yaş aralığında olup bu grubu (33\%) 25-30 yaş aralığı izlemektedir. Katılımcıların büyük bir kısmı lisans mezunu (79\%) olup ardından ön lisans (11\%) ve yüksek lisans (9\%) mezunları gelmektedir. Banka çalışanlarının eğitim alanları incelendiğinde ilk sırada Ekonomi/İktisat (48\%) alanı yer alırken ikinci sırada İşletme/Yönetim (38\%) alanı bulunmaktadır. Mühendislik alanında eğitim alanların oranı ise (4\%) düşüktür. Son olarak katılımcıların $\% 43$ ’ü kadındır.

Türkiye Bankalar Birliği (2019) verilerine göre, sektördeki toplam çalışan sayıs1 190.908 kişi olup, kadın çalışan oranı yüzde 51, erkek çalışan oranı ise yüzde 49'dur.Bankacılık sektöründe çalışanların yüzde 78'i yükseköğretim kurumları mezunu, yüzde 8'i ise yüksek lisans ve doktora yapmış kişilerden oluşmaktadır. Bu oran orta öğretim için yüzde 13'tür. Araştırmanın demografik sonuçları ile Türkiye Barolar Birliği verilerinin benzer nitelikte olduğunu söylemek mümkündür.

\subsection{Bulgular}

\subsubsection{Mevcut Durumun Belirlenmesi}

Bankacılık sektöründe teknoloji kullanımına yönelik mevcut durumun belirlenmesi amacıyla yapılan bu araştırmada kullanılan soru formunda yer alan ölçek ifadelerine ilişkin katılımcı görüşleri frekans ve yüzde dağılımları ile belirlenmiştir. Bu doğrultuda, araştırmanın nedensonuç ilişkisini ortaya koyan bir araştırma olmadığı, mevcut durum tespitini ortaya koymayı hedefleyen bir çalışma olduğunu belirtmek gerekir.

Soru formunda ilk bölümde yer alan ilk soru banka çalışanlarının her bir elektronik dağıtım kanalına verdiği önemi tanımlama amacını taşımaktadır. Tablo 1'de görüldüğü üzere çok tercih edilen dağıtım kanalı internet olmuştur. Ardından mobil cihaz ve ATM gelmektedir. Müşterilerin çeşitli bankacılık işlemlerini gerçekleştirebilmek amacıyla banka şubelerini ziyaret etme durumları gittikçe azalmakta, bu durum banka çalışanlarının çalışma rutinlerini ciddi oranda etkilemektedir. Bankalar bilinçli bir strateji güderek bazı rutin operasyonları için şubeden işlem yapmayarak müşterilerini elektronik dağıtım kanallarına yönlendirerek bu durumu desteklemektedirler. 
Tablo 1. Bankacılık faaliyetlerindeki elektronik dağıtım kanalına verilen önem derecesi

\begin{tabular}{|c|c|c|c|c|c|c|c|c|c|c|c|c|c|}
\hline & & & & 1 & & 2 & & 3 & & 4 & & 5 & \\
\hline & Ort & Mod & Std.S. & $\mathbf{N}$ & $\%$ & $\mathbf{N}$ & $\%$ & $\mathbf{N}$ & $\%$ & $\mathbf{N}$ & $\%$ & $\mathbf{N}$ & $\%$ \\
\hline ATM & 4,05 & 5 & 1,11 & 8 & 3,3 & 19 & 7,7 & 41 & 16,7 & 64 & 26 & 114 & 46,3 \\
\hline Extranet & 2,93 & 1 & 1,5 & 67 & 27,2 & 33 & 13,4 & 51 & 20,7 & 42 & 17,1 & 53 & 21,5 \\
\hline İnternet & 4,58 & 5 & 0,84 & 2 & 0,8 & 6 & 2,4 & 26 & 10,6 & 51 & 20,7 & 161 & 65,4 \\
\hline $\begin{array}{l}\text { Mobil } \\
\text { cihaz }\end{array}$ & 4,39 & 5 & 0,91 & 5 & 2,0 & 6 & 2,4 & 25 & 10,2 & 63 & 25,6 & 147 & 59,8 \\
\hline Telefon & 3,47 & 5 & 1,31 & 19 & 7,7 & 52 & 21,1 & 38 & 15,4 & 68 & 27,6 & 69 & 28 \\
\hline
\end{tabular}

Elde edilen ortalamalara ilişkin önem dereceleri incelendiğinde, İnternet seçeneğinin 4,58 ve Mobil cihaz seçeneğinin 4,39 değerini aldığ 1 görülmektedir. Her iki seçenek de bankacılık işlemlerinde artan oranda tercih edilen seçeneklerdendir.

İlk bölümün ikinci sorusunda, bu elektronik dağıtım kanallarından hangisinin son bir yıl içinde en çok büyüme ve gelişmeyi gösterdiğinin ortaya çıkarılması amaçlanmıştır. İlk soruya verilen cevaplara benzer şekilde en çok mobil cihaz $(n=113)$ seçeneği işaretlenmiştir. Bu seçeneği internet $(n=98)$ izlemektedir. Her iki kanal için de kullanım olanakları yeni teknolojilerin etkisiyle sürekli gelişme göstermekte, bankacılık işlemleri daha çok bu kanallar vasıtasıyla gerçekleştirilmektedir. 22 katılımcı ATM'yi işaretlerken, 8 katılımcı da Extranet'in büyüme kaydettiğini düşünmektedir. Verilen seçeneklerden en düşük değeri telefon almış( $(n=4)$, bir katılımcı da diğer seçeneği altında şube seçeneğini( $n=1)$ eklemiştir.

Reis, Ferreira ve Barata'nın (2013) Portekiz'in bir bölgesinde yaptıkları benzer çalışmanın sonuçlarında bundan yaklaşık 6 sene önce ilk sırada ATM yer almakta onu İnternet seçeneği izlemekte ve mobil cihaz seçeneği gerilerde kalmaktadır. Ancak bugün geldiğimiz noktada bu durum değişmiştir. Mobil cihaz ilk sıraya yerleşmiş, ATM seçeneği gerilemiştir. Bunun en büyük sebebi mobil cihazların oldukça yaygınlaşması sonucunda şubeye gitmek yerine bulunduğu bölgeye en yakın ATM'yi tercih eden müşterilerin artık ATM'ye de gitmediği ve bulunduğu yerden mobil cihazını kullanarak bankacılık işlemlerini dijital olarak gerçekleştirebilmesi olarak görülmektedir. Elbette ki bu durumu sağlayan ana unsur, arka plandaki teknoloji ile birlikte mobil cihazlarda kullanılabilen bankacılık uygulamalarının geliştirilmiş olmasıdır.

İlk bölümün son sorusu, banka çalışanlarının günlük faaliyetlerinin bir parçası olarak hangi faaliyetlerin teknolojiye daha çok bağlı olduğuna yönelik düşünceleri ile ilgilidir. Bu soru için verilen sekiz seçenekten en fazla dördünün işaretlenmesi istenmiştir. Elde edilen cevaplar Tablo 2'de yer almaktadır. 
Tablo 2. Yeni teknolojilere yüksek düzeyde bağlı olan bankacılık işlemleri

\begin{tabular}{|l|l|l|}
\hline & $\mathbf{N}$ & $\mathbf{\%}$ \\
\hline Bakiye sorgulama, hesap hareketleri & 171 & 18,6 \\
\hline Aktivasyon, bilgi sorgulama ve kart operasyonları & 164 & 17,8 \\
\hline Kurum ödemeleri (ör.gelir vergisi, KDV., damga vergisi) & 152 & 16,5 \\
\hline E-mail ve SMS ile planlanan transfer uyarıları ve ödemeleri & 124 & 13,5 \\
\hline Hizmet ödemeleri & 112 & 12,2 \\
\hline Ulusal ve yabancı transferler & 99 & 10,8 \\
\hline Hareket raporlarının excele aktarımı & 60 & 6,5 \\
\hline Çek isteği ve iptalleri & 35 & 3,8 \\
\hline Diğer (Lütfen belirtiniz....................................... & 3 & 0,3 \\
\hline
\end{tabular}

Yukarıdaki veriler değerlendirildiğinde, sırasıyla bakiye sorgulama, hesap hareketleri; aktivasyon bilgi sorgulama ve kart operasyonları, kurum ödemeleri; E-mail ve Sms ile planlanan transfer uyarıları ve ödemeleri işlemlerinin teknolojiye bağımlılığının en yüksek dört işlem olduğu görülmektedir. Bunun yanı sıra çek isteği ve iptalleri de günümüzde ödeme yöntemi olarak çeklerin kullanımının azalmasıyla orantılı olarak son sırada yer almıştır.

\subsubsection{Yeni Teknolojiler ve Çalışanlara Etkileri}

Soru formunun ikinci kısmında yer alan ifadeler vasıtasıyla, bilgi ve iletişim teknolojilerinin banka çalışanlarına ve gerçekleştirdikleri bankacılık faaliyetlerine etkisi sorgulanmaya çalışılmıştır. Bu doğrultuda ilk soruda en çok etkilendiklerini düşündükleri dört faaliyeti seçmeleri istenmiştir. Tablo 3'de verilen cevaplar en yüksek puan alandan en düşük puan alana doğru sıralanmıştır.

Tablo 3. Banka çalışanlarının bilgi ve iletişim teknolojilerinden en çok etkilendiğini düşündükleri bankacilık faaliyetleri

\begin{tabular}{|l|l|l|}
\hline & $\boldsymbol{N}$ & $\mathbf{\%}$ \\
\hline Kredi & 199 & 20,8 \\
\hline Uygulamalar & 165 & 17,2 \\
\hline İsleme ve veri yönetimi & 162 & 16,9 \\
\hline Hizmetler & 149 & 15,6 \\
\hline Muhasebe & 129 & 13,5 \\
\hline Uluslararası operasyonlar & 102 & 10,5 \\
\hline Hazine & 53 & 5,5 \\
\hline
\end{tabular}

Verilen cevaplar incelendiğinde ilk sırada kredi faaliyeti bulunmasına karşın alt sıralarda yer alan diğer faaliyetlerle aralarında çok büyük farklar olmadığı görülmektedir. Bilgi ve iletişim teknolojilerinin en az etkilendiği düşünülen faaliyet ise hazine olarak yer almaktadır. 
Cevaplar sonucunda banka çalışanları, günlük işlemlerinin çoğunun bilgi teknolojileri kullanımından etkilendiğini düşünmektedir.

Bir sonraki soru bilgi ve iletişim teknolojilerinin günlük faaliyetlere getirmiş olduğu en büyük avantajın ortaya çıkarılması amacını taşımaktadır. Elde edilen cevaplara göre, söz konusu avantajlar; verimlilik, hatalarda düşüş, isteklendirme, kalite ve hız olarak sunulmuştur. $\mathrm{Bu}$ soruya verilen cevaplar incelendiğinde, banka çalışanlarının yarısı $(50,8 \%)$ hız yanıtını vermiştir. Buradan anlaşılmaktadır ki, banka çalışanları için teknolojinin mevcut bankacılık faaliyetlerine getirdiği en büyük fayda işlemlerin daha hızlı gerçekleştiriliyor oluşudur. Böylece bilgi ve iletişim teknolojileri, her geçen gün artan hizmetler ve yoğunlaşan iş temposu için zaman kazandırmaktadır. Geriye kalan seçenekler ise verimlilik $(25,2 \%)$, daha az hata $(13,8 \%)$, kalite $(7,7 \%)$ ve motivasyon $(2,4 \%)$ olarak dağılım göstermektedir.

Banka çalışanlarına bilgi ve iletişim teknolojilerinin getirdiği en büyük avantajın ardından en büyük dezavantajın ne olduğu sorulmuştur. Dezavantajlar arasında en yüksek oran insan teması kaybına $(41,1 \%)$ ait olmuştur. İnsan teması kaybına ilişkin dezavantajını sırasıyla, yüksek düzey istek ve gereksinimler (20,3\%), azalan özerklik (13\%), sürekli öğrenme ihtiyac1 $(10,2 \%)$, iş yükü artışı $(8,9 \%)$ ve yerine getirilecek görevlerde değişim $(6,5 \%)$ izlemiştir. İnsan teması kaybının açık arayla en büyük dezavantaj olmasının nedeni bilgi ve iletişim teknolojileriyle banka şubesine gitmeye gerek kalmadan, herhangi bir banka personeliyle görüşmeden müşterilerin sanal bir şekilde işlemlerini kendi başlarına gerçekleştirebiliyor olmalarından kaynaklanmaktadır. Özellikle rutin işlemlerin yapılmasında (bakiye sorgulama, para transferi, iban sorgulama gibi) müşteri mobil cihaz veya internet gibi elektronik dağıtım kanallarını kullanarak işlemini çalışan ile temasa geçmeden yapabilmektedir. Nadir olarak telefon bankacılığında veya internet üzerinden işlem yaparken kullanılan anlık mesajlaşma ile banka personeli ve müşteri kontağı kurulabilmektedir. İkinci sıradaki dezavantaj ise yüksek düzey istek ve gereksinimler olarak belirtilmiştir. Rekabetin de etkisiyle bilgi ve iletişim teknolojileri kullanımıyla sunulan hizmet ve olanaklar müşterilerin daha da talepkâr olmasına yol açabilmektedir. Bununla birlikte, kullanılan teknolojilere yönelik öğrenme ihtiyacı da ortaya çıkmaktadır. Tercih edilen teknolojilerin kullanıcı dostu olması ve kullanım kolaylığı ve kullanışlılık özelliklerine de sahip olması gerekmektedir. Kuramsal çerçevede ele alınan modeller de teknoloji kullanımında bu özelliklerin uyumluluğunu savunmaktadır (Davis, 1993; Goodhue ve Thompson,1995)

Katılımcılara bilgi ve iletişim teknolojileriyle birlikte banka çalışanlarının günlük faaliyetlerinin hangi yönden değiştiğine dair bir soru yöneltildiğinde verilen cevaplardan ilk sırayı çok yönlülük seçeneği $(37,8 \%)$ almıştır. Ardından en çok verilen cevap ise, hizmet hacmi $(32,9 \%)$ olmuştur. İlk iki sırayı paylaşan bu cevaplar aslında birbirini tamamlamaktadır. Hizmet uyarlaması $(25,2 \%)$ ise üçüncü sıradadır. Bankaların verdiği hizmetler çeşitlendikçe yapılan işlemlerin sayısı da yükselmektedir. Bundan 5 yıl öncesiyle kıyaslandığında bugün gerek banka şubelerinden gerekse elektronik dağıtım kanallarından gerçekleştirilebilen birçok yeni işlem bulunmakta, bu işlemlerin sayısı bankalar arası rekabetin de etkisiyle her geçen gün artmaktadır. Son sırada ise düşük bir oranla çalışma saatleri $(4,1 \%)$ gelmektedir. Bu durumda banka çalışanlarının bilgi ve iletişim teknolojilerinin etkisiyle çalışma saatlerinde bir değişiklik olmadığını düşündüklerini söylemek mümkünüdür.

Elbette ki teknolojik yenilikler emek yoğun bir sistemden makine veya bilgisayar yoğun bir sisteme geçişi sağlamaktadırlar. Bu durum banka çalışanları açısından düşünüldügünde, katılımcılara bilgi ve iletişim teknolojilerinin kariyerleri açısından ne tür bir etkisi olduğu 
sorusu yöneltilmiştir. Verilen cevaplar incelendiğinde, banka çalışanlarının yarısından fazlası bu durumu daha iyi nitelik (43,1\%) ve kariyer gelişim firsatı $(23,2 \%)$ olarak görmektedirler. $\mathrm{Bu}$ açıdan bakıldığında, bankacılıkta teknoloji geliştikçe mevcut çalışanlar arasından daha iyi özelliklere sahip olanların ön plana çıkacağı ve onlar açısından kariyerlerinde avantajlı durumlar oluşacağı sonucu çıkarılabilir. Diğer taraftan, katılımcıların bir kısmı da işsizlik (24\%) ve kariyer durgunluğu $(9,8 \%)$ cevabını vermişlerdir ki istenen özelliklere sahip olmayan mevcut çalışanlar açısından da işten çıkarılma veya kariyerinde yükselememe gibi sonuçlarla karşılaşılması muhtemel olacaktır. Bu durum da banka çalışanlarının kariyerleri açısından teknolojik yeniliklerin olumsuz tarafını göstermektedir. Ayrıca geçmiş yıllara ait bankacılık verilerine bakıldığında da, banka şubelerindeki toplam çalışan sayısının geçmiş y1llara göre bir düşüş eğiliminde olduğu da görülmektedir.

Bilgi ve iletişim teknolojileriyle birlikte gerçekleşen değişimin olumsuzluk şeklinde algılanan bir yönü de bankacılık faaliyetlerinde güven sorunudur. $\mathrm{Bu}$ nedenle banka çalışanlarına yöneltilen bir sonraki soru bankacılık sektöründe hangi alanlarda güvensizlik durumu geliştiği olmuştur. Verilen seçeneklerden en çok dördünü seçmeleri istenen banka çalışanlarının cevapları Tablo 4'de özetlenmektedir.

Tablo 4. Banka çalışanlarının bilgi ve iletişim teknolojileriyle birlikte güvensizlik durumu geliştiğini düşündükleri alanlar

\begin{tabular}{|l|l|l|}
\hline & N & \% \\
\hline İşücü yapısı & 144 & 15,4 \\
\hline Yeterlilikler ve beceriler & 139 & 14,9 \\
\hline Istihdamda istikrarsızlık & 129 & 13,8 \\
\hline Faaliyet ve iş & 123 & 13,2 \\
\hline Terfi ve kariyer gelişimi & 121 & 13 \\
\hline Işin fiziki ortamı & 102 & 10,9 \\
\hline Verimlilik & 89 & 9,5 \\
\hline İs ilanlarında istikrar & 86 & 9,2 \\
\hline
\end{tabular}

Tablo 4 incelendiğinde, banka çalışanlarının güvensizlik geliştiğini düşündükleri alanların başında işgücü yapısı gelmektedir. Bilgi ve iletişim teknolojileri ile birçok işlem elektronik dağıtım kanallarına devredilerek mevcut personelin gerçekleştirdiği işlerin yapısının sürekli değişmesi gündeme gelmektedir. İkinci sırada, yeterlilikler ve beceriler gelmektedir. Rutin işlemler müşteriler tarafından ağırlıklı olarak banka şubesine gitmeden gerçekleştirilmekte, rutin olmayan ve karmaşık yapıdaki işlemler için de banka şubelerine başvurulmaktadır. Bu durumda şube personelinin çeşitli eğitimlerle kendini sürekli geliştirmesi gerekmektedir. Verilen diğer cevaplar da birbirine yakın puanlar almıştır. Yukarıda sayılan açıklamalar istihdamda istikrarsızlık seçeneği için de geçerlidir. Hızlı teknolojik gelişmeler, yeni personel istihdamını azaltma yönünde rol oynamaktadır. 


\subsubsection{Bankacılık ve Yenilik}

Soru formunun üçüncü grubunda yenilikçi eğilimlerle ilgili tahminlere ayrılan sorular, teknolojik yeniliğin bankacılık ürün ve hizmetlerindeki etkisini ortaya çıkarmayı hedeflemektedir. $\mathrm{Bu}$ doğrultuda, ilk soru hangi ATM operasyonunun insan kaynaklarının günlük rutinine daha çok etkisi olduğunu tanımlamaya yönelik olmuştur. Bu soru için katılımcıların verilen seçeneklerden en çok dördünü seçmeleri istenmiştir. Elde edilen yanıtlar Tablo 5'de siralanmaktadir.

Tablo 5. Bankacılıkta insan kaynaklarının yapılanmasına en çok etkisi olduğu düşünülen ATM işlemleri

\begin{tabular}{|l|l|l|}
\hline & N & \% \\
\hline Hesap no, IBAN sorgulama & 162 & 17,3 \\
\hline Para çekme & 156 & 16,6 \\
\hline Hesap hareketleri & 143 & 15,3 \\
\hline Bakiye sorgulama & 132 & 14,1 \\
\hline Bankalararası transferler & 130 & 13,9 \\
\hline Iç transferler & 124 & 13,2 \\
\hline Direkt borçlar & 50 & 5,3 \\
\hline Teslimatlar ve depozitolar & 41 & 4,4 \\
\hline
\end{tabular}

Verilen yanıtlara göre, direkt borçlar ile teslimatlar ve depozitolar seçenekleri dışında kalan diğer seçenekler birbirine yakın puanlar almışlardır. Seçeneklerde belirtilen işlemler müşteriler tarafından sıklıkla yapılan işlemler olduğu için aralarında büyük puan farklılıkları yoktur. Örneğin para çekmek için ATM'ye giden bir müşteri aynı zamanda bakiyesine de bakabilmekte veya hesap hareketlerini de inceleyebilmektedir. Özetle, bu işlemler ATM'ler ile gerçekleştirilebildiği için müşterinin şubeye gitmesine gerek kalmamakta, bu durum da şube personeli için insan kaynakları yapılanmasını etkilemektedir.

Bir sonraki soru internet bankacılığı ile mobil bankacılığın devreye girmesiyle birlikte en çok hangi işlemde düşüşün gerçekleştiği hakkındadır. Verilen cevaplar Tablo 6'da özetlenmektedir. 
Tablo 6. İnternet ve mobil bankacılık ile en çok düşüş kaydedilen şube işlemleri

\begin{tabular}{|l|l|l|}
\hline & $\mathbf{N}$ & $\mathbf{\%}$ \\
\hline Bakiye sorgulama & 56 & 22,8 \\
\hline Bankalar arasi transferler & 55 & 22,4 \\
\hline Hesap hareketleri & 50 & 20,3 \\
\hline Iç transferler & 33 & 13,4 \\
\hline Hizmet ödemeleri & 18 & 7,3 \\
\hline Direkt borçlar & 13 & 5,3 \\
\hline Hesap no, Iban sorgulama & 8 & 3,3 \\
\hline Teslimatlar ve depozitolar & 8 & 3,3 \\
\hline Diğer & 5 & 2 \\
\hline
\end{tabular}

Söz konusu işlemler incelendiğinde ilk üç sırada bakiye sorgulama, bankalar arası transferler ve hesap hareketleri gelmektedir. Bunlardan bakiye sorgulama ve hesap hareketleri işlemleri birbirini genellikle tamamlayan işlemlerdir. Müşteriler rutin olarak bilgi edinmek amacıyla bu işlemleri günün herhangi bir saati gerçekleştirebilmektedirler. Bu işlemler için günümüzde banka şubesine gitmek olası bir hareket değildir. Transfer işlemleri (örn. eft) için de banka şubesine gitmek zaman kaybı olarak görüldüğünden tercih edilmemektedir.

İnternet bankacılığı ve mobil bankacılık hizmetleri düşünüldüğünde mevcut gerçekleştirilen hizmetlerde öncesine göre temel avantajın ne olduğu bir başka soru olarak yer almıştır. $\mathrm{Bu}$ sorunun üç seçeneği mevcuttur: etkinlik, güvenlik ve hız. Banka çalışanları ağırlıklı olarak hız $(74,4)$ cevabını vermişlerdir. Güvenlik $(14,2 \%)$ ve etkinlik $(11,4 \%)$ de kalan kısmı birbirine yakın oranlarda bölüşmüştür. Cevaplar değerlendirildiğinde, hız seçeneğinin çoğunluk tarafından tercih edilme sebebi müşterinin zaman kazanmak ve işlemleri vakit kaybetmeden gerçekleştirmek için internet ve mobil bankacılık sistemlerini benimsemiş olduğu gerçeğindedir. Zaten bu sistemlerin sunulmalarının altında yatan sebep daha kısa zamanda daha çok işlem yapılabilmesidir. Güvenlik ve etkinlik açısından değerlendirildiğinde ise, yeni teknolojilerin eski sistemlere göre bu iki özellik için çok büyük bir avantaj getirmediği düşünülmektedir.

Bir sonraki soruda katılımcılara, bilgi ve iletişim teknolojilerinin bir ürünü olan tek kullanımlık şifre teknolojisi için müşterilerinin güven düzeyini nasıl değerlendirdikleri sorulmuştur. Tablo 7'de verilen cevaplar yer almaktadır. Genel olarak, banka çalışanları tarafından güven düzeyinin yüksek olduğu düşünülmektedir. 
Tablo 7. Banka çalışanları tarafından tek kullanımlık şifre teknolojisi için müşterilerin güven düzeyinin değerlendirilmesi

\begin{tabular}{|l|l|l|}
\hline & $\mathbf{N}$ & $\%$ \\
\hline$\% 0-20$ & 3 & 1,2 \\
\hline$\% 20-40$ & 15 & 6,1 \\
\hline$\% 40-60$ & 56 & 22,8 \\
\hline$\% 60-80$ & 82 & 33,3 \\
\hline$\% 80-100$ & 90 & 36,6 \\
\hline
\end{tabular}

Bir başka soruda satış ve hizmet noktası (POS) ve mail order uygulamalarının en büyük avantajının ne olduğunu ortaya çıkarmak hedeflenmiştir. Verilen seçenekler değerlendirildiğinde ilk sırayı sağlanan hizmet hızı $(40,2 \%)$ almıştır. Daha önce yöneltilen benzer sorulardaki gibi hız seçeneği ön sıradadır. Ardından müşteri memnuniyeti $(33,3 \%)$ gelmektedir. Müşteriler yanında para taşımalarına veya para çekmelerine gerek kalmadan bu iki sistem sayesinde ödemelerini kolaylıkla yapabilmektedirler. Üçüncü sırada maliyet düşüşü $(16,7 \%)$ bulunurken en düşük payı şubelere müşteri girişinin azalması $(9,3 \%)$ seçeneği almıştır.

$\mathrm{Bu}$ grubun bir diğer sorusu, müşteri yaş grubu bakımından değerlendirdiğinizde, bilgi ve iletişim teknolojilerine müşterilerinizin bağlılığını nasıl yorumlarsınız şeklinde katılımcılara yöneltilmiştir. Amaç müşterilerin yaş grubu ile bilgi ve iletişim teknolojileri arasındaki ilişkiyi anlamaktır. Bu soru 1'den 5'e kadar Likert ölçeği kullanılarak sorulmuştur. Elde edilen cevaplar Tablo 8'de gösterilmektedir.

Tablo 8. Yaş gruplarına göre bilgi ve iletişim teknolojilerine bağlılık

\begin{tabular}{|c|c|c|c|c|c|c|c|c|c|c|c|c|}
\hline & & & \multicolumn{2}{|l|}{1} & \multicolumn{2}{|l|}{2} & \multicolumn{2}{|l|}{3} & \multicolumn{2}{|l|}{4} & \multicolumn{2}{|l|}{5} \\
\hline & Ort & Std.S. & $\mathrm{N}$ & $\%$ & $\mathrm{~N}$ & $\%$ & $\mathrm{~N}$ & $\%$ & $\mathrm{~N}$ & $\%$ & $\mathrm{~N}$ & $\%$ \\
\hline 21 yaşından küçük & 3,69 & 1,41 & 31 & 12,6 & 21 & 8,5 & 44 & 17,9 & 45 & 18,3 & 105 & 42,7 \\
\hline $21-25$ arast & 4,43 & 0,93 & 4 & 1,6 & 10 & 4,1 & 22 & 8,9 & 50 & 20,3 & 160 & 65 \\
\hline 26-30 arast & 4,34 & 0,82 & 2 & 0,8 & 3 & 1,2 & 34 & 13,8 & 78 & 31,7 & 129 & 52,4 \\
\hline $31-40$ arast & 3,81 & 0,99 & 3 & 1,2 & 21 & 8,5 & 67 & 27,2 & 84 & 34,1 & 71 & 28,9 \\
\hline 41-50 arast & 2,97 & 1,04 & 21 & 8,5 & 53 & 21,5 & 103 & 41,9 & 50 & 20,3 & 19 & 7,7 \\
\hline 51-60 arast & 2,07 & 1,09 & 86 & 35 & 99 & 40,2 & 31 & 12,6 & 19 & 7,7 & 11 & 4,5 \\
\hline 61 yaşından büyük & 1,48 & 1,05 & 188 & 76,4 & 31 & 12,6 & 7 & 2,8 & 8 & 3,3 & 12 & 4,9 \\
\hline
\end{tabular}

Beklenildiği üzere genç yaş grupları için bağlılık oldukça yüksektir. Mod değerlerine bakıldığında 21 ile 30 yaş arası en çok 5 yanıtı verilmiş olduğu görülmektedir. Bu değer yaş grubu yükseldikçe 1'e doğru düşmektedir. Bağlantılı olarak yüzde değerleri de aynı şekilde değişmektedir. Genç yaş grubu teknolojiyle birlikte büyüdüğü için bilgi ve iletişim teknolojilerine bağlılık daha fazladır. Teknolojiyle daha sonradan tanışan ileriki yaş grupları için alışkanlık, güven veya öğrenme güçlüğü gibi sebeplerden teknoloji bağlılığı yaygın değildir. 
Bir başka soru yeni elektronik dağıtım kanallarının güvenlik düzeyleri hakkındadır. Bu soruda da 5'li Likert ölçeğinden faydalanılmıştır. Elde edilen cevaplar Tablo 9'da yer almaktadir.

Tablo 9. Elektronik dağıtım kanallarına olan güven düzeyi

\begin{tabular}{|c|c|c|c|c|c|c|c|c|c|c|c|c|}
\hline & \multirow[b]{2}{*}{ Ort } & \multirow[b]{2}{*}{ Std.S. } & \multicolumn{2}{|l|}{1} & \multicolumn{2}{|l|}{2} & \multicolumn{2}{|l|}{3} & \multicolumn{2}{|l|}{4} & \multicolumn{2}{|l|}{5} \\
\hline & & & $\mathrm{N}$ & $\%$ & $\mathrm{~N}$ & $\%$ & $\mathrm{~N}$ & $\%$ & $\mathrm{~N}$ & $\%$ & $\mathrm{~N}$ & $\%$ \\
\hline ATM & 4,13 & 1,02 & 7 & 2,8 & 12 & 4,9 & 36 & 14,6 & 78 & 31,7 & 113 & 45,9 \\
\hline Extranet & 3,25 & 1,38 & 42 & 17,1 & 32 & 13 & 47 & 19,1 & 73 & 29,7 & 52 & 21,1 \\
\hline Internet & 3,96 & 0,96 & 5 & 2 & 14 & 5,7 & 46 & 18,7 & 102 & 41,5 & 79 & 32,1 \\
\hline Mobil Cihaz & 3,96 & 1,00 & 3 & 1,2 & 24 & 9,8 & 37 & 15 & 99 & 40,2 & 83 & 33,7 \\
\hline Telefon & 3,33 & 1,29 & 29 & 11,8 & 40 & 16,3 & 49 & 19,9 & 78 & 31,7 & 50 & 20,3 \\
\hline
\end{tabular}

Belirtilen elektronik dağıtım kanallarına duyulan güven düzeyi, ilgili dağıtım kanalının sunulması ve kullanımıyla paralel olarak değişmektedir. Bu doğrultuda, ATM ilk olarak sunulan elektronik dağıtım kanalı olduğu için güven düzeyinin en yüksek algılandığı araçtır. Banka müşterileri arasında elektronik dağıtım kanallarının kullanımı yaygınlaştıkça tercih edilme ve güven düzeyi de artmaktadır. Mod değerlerine bakıldığında her bir araç için en çok verilen cevabın 4 olduğu görülmektedir. Bu durumda kendi içinde değişen güven düzeyleri olsa da her bir elektronik dağıtım kanalı için yüksek seviyede güven duyulduğunu söylemek mümkündür.

Banka çalışanlarına yöneltilen bir diğer soruda, teknolojik yenilikleri kolaylaştırdığını düşündükleri faktörlerden dört tanesini seçmeleri istenmiştir. Bu faktörler bağlantı, müşteri ilişkisi, e-ticaret, iş odaklılık, küresel rekabet, değer zincirinin entegrasyonu ve işi büyütme arayışı olarak sıralanmıştır. İşi büyütme arayışı dışında verilen seçenekler birbirine yakın değerler almıştır. İlk iki sırayı e-ticaret $(20,3 \%)$ ve müşteri ilişkisi $(19,4 \%)$ paylaşmıştır. Ardından iş odaklılık (16,7\%), değer zincirinin entegrasyonu $(16,2 \%)$ ve bağlantı $(15,5 \%)$ gelmektedir.

Son soruda, banka çalışanlarından teknolojik yenilikleri engellediğini düşündükleri dört faktörü seçmeleri istenmiştir. Bu faktörler Tablo 10'da sıralanmaktadır.

Tablo 10. İnovasyonu engellediği düşünülen faktörler

\begin{tabular}{|c|c|c|}
\hline & $\mathbf{N}$ & $\%$ \\
\hline Pazar hakkında bilgi yetersizliği & 163 & 17,1 \\
\hline Teknoloji hakkında bilgi yetersizliğ $i$ & 156 & 16,3 \\
\hline Uygun finansman kaynaklarının eksikliği & 154 & 16,1 \\
\hline Ekonomik risklerde artış algısı & 124 & 13 \\
\hline Yeni ürünlerin müşsterilerce beğenilme azlı̆̆g & 123 & 12,9 \\
\hline Yenilik maliyetleri & 120 & 12,6 \\
\hline Esnek olmayan organizasyon yapısı & 116 & 12,1 \\
\hline
\end{tabular}


Verilen cevaplar değerlendirildiğinde ilk iki sırada pazar (17,1\%) ve teknoloji (16,3\%) hakkında bilgi yetersizliği yer almaktadır. Yeterli bilgiye sahip olamamanın teknolojik yenilikleri etkilediği ve engellediği düşünülmektedir. Ardından ekonomik engeller gelmektedir. Uygun finansman kaynaklarının eksikliği (16,1\%), ekonomik riskler (13\%) ve yenilik maliyetleri $(12,6 \%)$ sıralanmaktadır. Diğer engeller ise, yeni ürünlerin müşteriler tarafindan beğenilmemesi $(12,9 \%)$ ve esnek olmayan organizasyon yapısı $(12,1 \%)$ olarak belirtilmiştir.

\section{SONUÇ}

Bankacılık sektörü teknolojik gelişmelerden hızlı bir şekilde payını alarak değişim göstermektedir. Bu değişimin arkasındaki itici güç teknolojinin yanı sıra yoğun rekabet ortamıdır. Müşterilere daha iyi hizmet vererek sektördeki payını arttırmak için yarışan bankalar neredeyse her geçen gün yeni bir ürün, hizmet ya da uygulama geliştirmektedir. Buna ek olarak, Yetiz ve Ergin Ünal'ın (2018) da vurguladığı gibi bankalar, sektörde rekabet edebilmek, pazar payını artırmak ve devamlılığını kârlı bir şekilde devam ettirebilmek için finansal yenilikler kapsamında teknolojik değişimlere hızla uyum sağlayarak yeni ürünler geliştirerek maliyetlerini azaltmak zorundadır. Günümüzün başarılı bankaları, teknolojiyi yaygın bir şekilde kullanarak katma değerli ve yenilikçi ürünler sunan, değişimi etkin bir şekilde yönetebilen ve müşteri memnuniyetine önem veren bankalar olacaktır (Filiz, 2016; Uçkun vd., 2016; Aldas-Manzano vd., 2009; Işıı 2006)

Banka çalışanlarının katılımıyla teknolojik yeniliklerin bankacılık hizmetlerine etkilerinin araştırıldığı bu çalışmanın sonuçlarını üç bölümde değerlendirmek mümkündür. İlk bölümde mevcut durum sorgulanmıştır. Elektronik dağıtım kanallarını önem derecesine göre sıralandığında, ilk sırada "internet" yer almaktadır. İnterneti, mobil cihaz ve ATM takip etmektedir. Birkaç yıl öncesinin en çok tercih edilen dağıtım kanalı olan ATM (Reis, Ferreira ve Barata, 2013) biraz gerileyerek yerini internete bırakmıştır. Çünkü son yıllarda en çok büyüme mobil cihaz ve internette olmuştur. $\mathrm{Bu}$ araçlar sayesinde sıklıkla yapılan işlemler; bakiye sorgulama, hesap hareketleri, kart işlemleri, kurum ödemeleri ve transferler şeklindedir. Öncesinde şubeye giderek gerçekleştirilen birçok rutin işlem yeni teknolojiler sayesinde müsşerinin yerinden kalkmadan gerçekleştirebileceği, bu sayede hem müşteri hem de banka açısından zaman kaybettirmeyen işlemlere dönüşmüştür.

İkinci bölümde, yeni teknolojiler ve çalışanlara etkileri sorgulanmaktadır. Bilgi ve iletişim teknolojileri ile bankalar bünyesinde birçok operasyon etkilenmiştir. Kredi işlemleri, uygulamalar, işleme ve veri yönetimi, hizmetler en çok etkilenen operasyonlar olurken, bu operasyonların yapılış şekli ile birlikte çalışanların durumları da etkilenmektedir. Banka çalışanları daha hızlı, verimli ve daha az hata yaparak bu operasyonları yerine getirmektedirler. Bu avantajların yanı sıra insan teması kayb1, istek ve gereksinimlerin artması, azalan özerklik, sürekli öğrenme ihtiyacı, iş yükü ve yerine getirilecek görevlerin artışı gibi olumsuzluklar da gündeme gelmiştir. Tüm bunlar banka çalışanlarının gerçekleş̧irdiği işlemlere çok yönlülük getirmekte ve hizmet hacmini arttırmaktadır. Çalışma saatlerinde büyük bir değişiklik olmamış ancak müşterilerin taleplerinin artması ve yeni ürün ve hizmetlerin sunulması sebebiyle birçok rutin işlemin elektronik dağıtım kanalları vasıtasıyla müşterilerce yapılmasına karşın banka çalışanlarının yoğunluğu azalmamış, aksine artmıştır. Bununla birlikte, banka çalışanlarının kariyerleri açısından bir değerlendirme yapılacak olursa, emek yoğun bir sistemden teknoloji yoğun bir sisteme geçilmesiyle personelin niteliğinin gelişmesi, mevcut personel için kariyer firsatları oluşumu gibi pozitif 
durumlar meydana getirmiştir. Özellikle iyi eğitimli ve genç çalışanlar için bu durum avantajlıdır. Ancak diğer taraftan, istenen özellikleri karşılamayan çalışanlar için kariyer durgunluğu ve işsizlik gibi sonuçlarla da karşılaşılmaktadır. Bu nedenle, işgücü yapısı, istihdam, terfi ve kariyer gelişimi açısından banka çalışanlarında güvensizlik durumu gelişmektedir.

Çalışmada teknolojik yeniliklerin etkisiyle bankacılık hizmetlerindeki eğilimler de incelenmiştir. İlk olarak ATM kullanımıyla gerçekleştirilen işlemlerin insan kaynaklarının yeniden yapılanmasındaki rolü sorgulanmıştır. Bu işlemler ATM kanalıyla yapılarak şube personelinin zamanını başka işlemlere ayırması veya farklı bankacılık operasyonlarında kendini geliştirmesi mümkün olmaktadır. Benzer şekilde internet bankacılığı ve mobil bankacılık sayesinde bu işlemler için şubeye gitmeye gerek kalmamıştır. Hatta bankalar bu durumu desteklemek amacıyla, bir takım işlemleri müşteri şubeye gitse bile şube personeli tarafından gerçekleştirmemekte, müşteriyi elektronik dağıtım kanallarına yönlendirmektedir. $\mathrm{Bu}$ durumun en büyük avantajı işlemlerin daha hızlı yapılması olmuştur. Benzer şekilde satış ve hizmet noktası (POS) ile mail order kullanımı, sağlanan hizmet hızını arttırmış ve müşteri memnuniyeti sağlamıştır.

Bilgi ve iletişim teknolojilerinin sorgulandığı bir diğer konu da hizmetlere duyulan güven hakkındadır. İşlemler yapılırken kullanılan tek kullanımlık şifre teknolojisine duyulan güvenin de ortalamanın üstünde olduğu görülmüştür. Elektronik dağıtım kanallarına duyulan güven düzeyi değerlendirildiğinde ilgili dağıtım kanalının yeniliği oranında güven düzeyi değişmektedir. Örneğin daha eski bir sistem olan ATM'ye duyulan güven internet ve mobil cihaza oranla daha fazladır.

Bilgi ve iletişim teknolojilerine müşteri bağlılığı ile yaş grubu arasındaki ilişki sorgulandığında ise, genç yaş grupları için bağlılığın yüksek olduğu ve yaş grubu yükseldikçe bağlılığın düştüğü ortay çıkmıştır. Bunun nedeni, teknoloji ile sonradan tanışan ileri yaş gruplarının bağlılık konusunda gerek alışkanlıklar gerekse öğrenme güçlüğü gibi sebeplerden sorun yaşamasıdır.

Son olarak, teknolojik yenilikleri kolaylaştırdığg ve engellediği düşünülen faktörler değerlendirilmiştir. E-ticaret, müşteri ilişkisi, iş odaklılık ve değer zincirinin entegrasyonu teknolojik yenilikleri kolaylaştıran en önemli faktörler olarak sıralanırken; pazar ve teknoloji hakkındaki bilgi yetersizliği ile finans kaynaklarının yetersizliği, ekonomik riskler ve yenilik maliyetleri gibi ekonomik faktörler teknolojik yenilikleri engelleyen temel faktörler olarak yer almıştır.

Günümüzde bankacılık sektöründeki teknolojik yenilikler sayesinde sunulan ürün ve hizmetler birçok kolaylığı beraberinde getirmiştir (Mehta, 2020). Bilgi teknolojilerinin kullanımı, müşteri memnuniyeti başta olmak üzere, sektör açısından da verimlilik ve karlılığı arttırmakta, daha rekabetçi bir sektör yaratmaktadır. Müşterilerine istediği zamanda, istediği yerde ve istediği şekilde bankacılık hizmetlerini sunabilen ve teknolojik dönüşümü etkin bir biçimde yönetebilen bankalar sürdürülebilir başarıyı elde ederek rekabet avantajına sahip olacaktır. Türkiye gibi genç nüfusa sahip, bilgi ve iletişim teknolojilerini yaygın bir şekilde kullanan bir ülke için bu potansiyelden yararlanarak yenilikçi ürün ve hizmetler sunmak bankacılık sektörünün geleceği için oldukça önemlidir.

Gerçekleştirilen bu çalışmada saptanan bulgular, banka çalışanlarının görüşlerinden elde edilen verilerin analizi sonucunda ortaya çıkmıştır. İlerleyen araştırmalarda, banka 240 
müşterilerinin de benzer sorulara verdiği yanıtların değerlendirilerek elde edilen sonuçların karşılaştırılması daha kapsamlı sonuçların ortaya çıkarılmasına katkı sunacaktır. Ayrıca bilgi teknolojileri kullanımına ilişkin kuramsal çatı ile desteklenen ve neden-sonuç ilişkisine sahip analizlerin yapılmasının da akademik ve sektörel gelişimin desteklenmesine fayda sağlayacağı öngörülmektedir.

\section{KAYNAKÇA}

ABBAS, J., MUZAFFAR, A., MAHMOOD, H. K., RAMZAN, M. A., \& RIZVI, S. S. U. H. (2014). "Impact Of Technology On Performance Of Employees (A Case Study On Allied Bank Ltd, Pakistan)”. World Applied Sciences Journal, 29(2), 271-276.

AJZEN, I. (1991). "The theory of planned behavior". Organizational behavior and human decision processes, 50(2), 179-211.

ALDÁS-MANZANO, J., LASSALA-NAVARRÉ, C., RUIZ-MAFÉ, C., \& SANZ-BLAS, S. (2009). "Key drivers of internet banking services use". Online Information Review, 33(4), 672-695.

ALIYU, A. A., \& TASMIN, R. B. (2012). "Information and Communication Technology in Nigerian Banks: Analysis of Services and Consumer Reactions". In proceedings of 3rd International Conference in Business and Economic Research, 150-164).

ARIKAN, B. (2015). “Türk bankacılığında inovasyon ve kreatif bankacılık”, İstanbul Ticaret Üniversitesi, Yüksek Lisans Tezi, İstanbul.

AYTAR, O., YEĞEN, İ., \& ERDEMIR, N. K. (2012). "Elektronik Şube ve Elektronik Bankacılık Hizmetleri”. Uşak Üniversitesi Akademik Bilişim Konferansı Bildiri Kitabı, 1-3.

BALAYLAR, A. N., \& DUYGULU, A. A. (2016). Finansal yenilikler ve para piyasas1-15. Bölüm-Para-Banka ve Finans Kitab1, Editörler: Nadir EROĞLU, Halil İbrahim AYDIN, Cüneyt Yenal KESBİÇ, Orion Kitabevi, Ankara.

BARLETT, J. E., KOTRLIK, J. W., \& HIGGINS, C. C. (2001). “Organizational research: Determining appropriate sample size in survey research". Information technology, learning, and performance journal, 19(1), 43-50.

BLACH, J. (2011). "Financial innovations and their role in the modern financial systemidentification and systematization of the problem". e-Finanse: Financial Internet Quarterly, 7(3), 13-26.

BOZAYKUT, T., KUYUCU, E., \& PINAR, I. (2016). "Investigating the Antecedents of Task-Technology Fit: A Field Study In Turkish Private Hospitals". International Journal of Business Information Systems, 22(4), 516-529.

BUZZACCHI, L., COLOMBO, M. G., \& MARIOTTI, S. (1995). “Technological regimes and innovation in services: the case of the Italian banking industry". Research Policy, 24(1), 151-168.

DAMANPOUR, F., \& GOPALAKRISHNAN, S. (2001). "The dynamics of the adoption of product and process innovations in organizations". Journal of management studies, 38(1), 45-65. 
DANIEL, P. E. Z., \& JONATHAN, A. (2013). "Factors affecting the adoption of online banking in Ghana: implications for bank managers". International Journal of Business and Social Research, 3(6), 94-108.

DAVIS, F. D. (1989). "Perceived usefulness, perceived ease of use, and user acceptance of information technology”. MIS quarterly, 319-340.

DAVIS, F. D. (1993). "User acceptance of information technology: system characteristics, user perceptions and behavioral impacts". International journal of man-machine studies, 38(3), 475-487.

DELONE, W. H., \& MCLEAN, E. R. (1992). "Information systems success: The quest for the dependent variable". Information systems research, 3(1), 60-95.

DOLL, W. J., \& TORKZADEH, G. (1988). “The measurement of end-user computing satisfaction”. MIS quarterly, 259-274.

EROL, İ., ÇINAR, S., \& DURAMAZ, S. (2015). “Bankaların Yeni Gelir Kaynağı: Elektronik Bankacılık İşlem Ücretleri, Türk Bankacılık Sektöründe Banka Kârlılığı Üzerindeki Etkisi”. Abant İzzet Baysal Üniversitesi Sosyal Bilimler Enstitüsü Dergisi, 15(2),1-21.

EY TÜRKIYE, “Gelişen Teknoloji, Bankacılıkta İşgücünü Dönüştürecek” tttp://www.ey.com/tr/ 31.10.2019.

FISHBEIN, M., \& AJZEN, I. (1975). Belief, Attitude, Intention and Behavior: An Introduction to Theory and Research, Addison-Wesley, Reading, MA.

FLAVIÁN, C., GUINALIU, M., \& TORRES, E. (2006). "How bricks-and-mortar attributes affect online banking adoption". International Journal of Bank Marketing, 24(6), 406423.

GHASEMI, M., SHAFEIEPOUR, V., ASLANI, M., \& BARVAYEH, E. (2011). “The impact of Information Technology (IT) on modern accounting systems". Procedia-Social and Behavioral Sciences, 28, 112-116.

GIATSIDIS, I., KITSIOS, F., \& KAMARIOTOU, M. (2019). "Digital Transformation and User Acceptance of Information Technology in the Banking Industry". In Proceedings of the 8th International Symposium \& 30th National Conference on Operational Research, Patras, Greece (6-10).

GOODHUE, D. L., \& THOMPSON, R. L. (1995). “Task-technology fit and individual performance". MIS quarterly, 213-236.

GUPTA, P., GUPTA, P., \& INDORIYA, N. (2020). "New Trends of Indian Banking Industry". Studies in Indian Place Names, 40(1), 311-319.

GÜVENÇ, D., \& YÜCEBALKAN, B. (2017). "Bankacılık Sektöründe Teknolojik Gelişimin İşü̈cüne Yansımaları”. Hukuk ve İktisat Araştırmaları Dergisi, 9(2), 30-43.

IŞIN, F. B. (2006). “Teknoloji Araçlarının Bankacılık Sektöründe Uygulanabilirliği Ve Türkiye'deki Bu Doğrultudaki Bankacılık Uygulamalarının Değerlendirilmesi”. Atatürk Üniversitesi İktisadi ve İdari Bilimler Dergisi, 20(2), 107-120. 
KAYA, F. \& ARSLAN, T. R. (2016). "İnternet Bankacılığında Müşterilerin Banka Tercihlerine Etki Eden Faktörler: Bolu İlinde Kamu Çalışanları Üzerine Bir Araştırma”. Finansal Araştırmalar ve Çalışmalar Dergisi 8(15), 423-449.

KOÇAK, S. B., \& ÖZBEK, C. Y.(2019). "Banka Müşterilerinin İnternet Bankacılığı Algısı Ve Hizmetlerine Dönük Görüşleri Üzerine Bir Araştırma: Burdur İli Bucak İlçesi Örneği’”. Bankacılık ve Finansal Araştırmalar Dergisi, 6(2), 87-99.

KUMAR, S. (2019). "A Study on The Impact of Technology on Banking Sector". International Journal of Research in Social Sciences, 9(1), 98-102.

KUO, Y. \& YE, K. (2010). “How Employees' Perception Of İnformation Technology Application And Their Knowledge Management Capacity Influence Organisational Performance". Behaviour \& Information Technology, 29(3), 287-303.

LIAO, Z., \& CHEUNG, M. T. (2002). "Internet-based e-banking and consumer attitudes: an empirical study". Information \& management, 39(4), 283-295.

MALIK, M. S., \& SATTAR, H. H. (2017). "The Effect Of Technology Perception Of Employees On Organizational Performance; In The Public And Private Bank So Of Pakistan". The Business \& Management Review, 9(2), 284-291.

MEHTA J. (2020) “The Future of the Banking Industry and Management Impact". In: Thakkar B. (eds) Paradigm Shift in Management Philosophy. Palgrave Macmillan, Cham

MOCETTI, S., PAGNINI, M., \& SETTE, E. (2017). "Information technology and banking organization". Journal of Financial Services Research, 51(3), 313-338.

NATH, R., BHAL, K. T., \& KAPOOR, G. T. (2013). "Factors Influencing It Adoption By Bank Employees: An Extended Tam Approach”. Vikalpa, 38(4), 83-96.

OO, C. Z. (2018). Employee Perception On Information And Communication Technology Practices In Co-Operative Bank, Yangon University of Economics, Doctoral Thesis.

PINTO, S., \& FERREIRA, F. (2010). "Technological dissemination in the Portuguese payments system: an empirical analysis to the region of Santarém". International Journal of Human Capital and Information Technology Professionals, 1(4), 55-75.

REIS, J., Ferreira, F., \& MONTEIRO B. J. (2013). "Technological innovation in banking services: an exploratory analysis to perceptions of the front office employee". Problems and Perspectives in Management, (1), 34-49.

RICHAD, R., VIVENSIUS, G., SFENRIANTO, S., \& KABURUAN, E. R. (2019). “Analysis of factors influencing millennial's technology acceptance of chatbot in banking industry in Indonesia”. International Journal of Civil Engineering and Technology, 10(4), 1270-1281.

ROBERTS, P. W., \& AMIT, R. (2003). "The dynamics of innovative activity and competitive advantage: The case of Australian retail banking". 1981 to 1995. Organization science, 14(2), 107-122. 
ROSE, E. A. S. (2020). "Modernization in Indian Banking Sector". Studies in Indian Place Names, 40(50), 4066-4070.

SUPING, H., \& YIZHENG, S. (2010). "Factors influencing user acceptance of online banking”. In 2010 International Conference on Logistics Systems and Intelligent Management, (1), 315-318.

SURYANINGRUM, D. H. (2012). “Assessing individual performance on information technology adoption: A new model”. Global Journal of Business Research, 6(4), 111125 .

SÜMER, G. (2016). "Türk Bankacilik Sektörünün Tarihsel Gelişimi Ve Ab Bankacilik Sektörü İle Karşilaştirilmasi”. Gazi Üniversitesi İktisadi ve İdari Bilimler Fakültesi Dergisi, 18(2), 485-508.

TAN, M., \& TEO, T. S. (2000). "Factors influencing the adoption of Internet banking". Journal of the Association for information Systems, 1(1), 5-44.

TÜRKIYE BANKALAR BİRLİĞİ. (2019). "Bankacılık Sisteminde Banka, Çalışan Ve Şube Sayıları”, http://tbb.org.tr/, 10.09.2019.

TÜRKIYE CUMHURIYETİ MERKEZ BANKASI. (2015). Finansal Istikrar: Türkiye'de Finansal Istikrar Gelişmeleri. Türkiye Cumhuriyet Merkez Bankası Yayınları. Ankara.

UÇKUN, C. G., YÜKSEL, A., UÇKUN, S., \& KARAKUZ, Ç. (2016). "Teknolojik Değişimin Banka Çalışanları Üzerindeki Etkilerinin İncelenmesi”. TURAN: Stratejik Araştırmalar Merkezi, 8(32), 255-264.

UGWU, L. O., OYEBISI, T. O., ILORI, M. O., \& ADAGUNODO, E. R. (2000). "Organisational Impact Of Information Technology On The Banking And Insurance Sector In Nigeria”. Technovation, 20(12), 711-721.

UZUN, U. \& BERBEROĞLU, M. (2018). "İnternet Bankacılığı Hizmetlerinin Banka Performansı Üzerine Etkisi. Uiiid-Ijeas,(20), 51-62.

VAN HORNE. J.C.(1985). “Of Financial Innovations and Excesses”. Journal of Finance, 40, 621-631.

VENKATESH, V., THONG, J. Y., \& XU, X. (2012). "Consumer acceptance and use of information technology: extending the unified theory of acceptance and use of technology”. MIS quarterly, 36(1), 157-178.

YETIZ, F. (2016). "Bankaciliğin Doğuşu Ve Türk Bankacilik Sistemi”. Niğde Üniversitesi İktisadi ve İdari Bilimler Fakültesi Dergisi, 9(2), 107-117.

YETİZ, F., \& ÜNAL, A. E.(2018). "Finansal Yeniliklerin Gelişimi Ve Türk Bankacılık Sektörüne Etkileri”. Kastamonu Üniversitesi İktisadi ve İdari Bilimler Fakültesi Dergisi, 20(4), 117-135.

YURTTADUR, M. ve SÜZEN, E. (2016), “Türkiye'de Banka Müşterilerinin İnternet Bankacılığına Yaklaşımlarının İncelenmesi Üzerine Bir Uygulama”. Tüketici ve Tüketim Araştırmaları Dergisi, 8(1), 93-120. 